力所において採取した結果, 高さによって異るが，お 上そ $20 \mathrm{~m}$ 地上高では，浮遊粉じんの MMDは抒上そ 10.5 1.0ミクロン位の間にある。各段フイルター上のサ ンプルは重量測定後, $\mathrm{pH}$, 特よび金属等の定量を行な うことができる。都市の大気污染では一般に最終段（小 粒子）に酸性が強くなることがみられた。さらに ring oven 法によって $\mathrm{Mn}, \mathrm{Co}, \mathrm{Pb}$ 等の測定が可能で市っ た。

以上の如く本法は $30 \mathrm{l} / \mathrm{min}$ の流量によるサンプルの 重量を測定することによてっ平均粒径を求めることがで き，さらに他の物質の測定が簡易に低経費でできる大き な特長があることを認め, 労衝衛生や公害対策に利用性 が大きい。

\section{8. 換気力学的見地よりみた呼吸装置の評価について}

梨本一郎, 大岩弘典, 北 博正 (東医菌大医衛生) 前田博（東医菌大医公衛）

粉じんや有毒ガス環境下で乎吸保護其として防じんマ スクや防毒マスク, あるいは自給式呼吸器具がもちいら れる。これら呼吸器具の評価にあたつては濾過吸収能ば かりでなく呼吸にたいする負荷の面を考光衫ばならな w。

呼吸抵抗に関しては装置の気流抵抗を連続流により湘 定しているにすぎなかったが呼吸生理学の面からは呼吸 のもつ波形数を考虑した正弦波気流汒よるのが適当であ る。そこで試作された正弦波呼吸ポンプにより種々調節 される正弦波気流により王一気流特性抢よび圧一量特性 をしり呼吸にたいする負哬量を客観的に評価する試みを 行なった。

自給式呼吸器の一種である, デマンドバルブ式呼吸装 置につき, 圧一気流, 圧一量, 特性を測定した結果, 台 日径, 呼吸膜, 供給圧の大なる活ど吸気仕事量が減少し 負荷の小さくなることをしり光た。

\section{9. 肺換気機能基準值（第 4 報）}

辻 義人, 角田文男, 田島良男（福島医大公衛）

肺換気機能基準值を設定するため，比較的空気の清㳙 な地区に䄧いて，8才の学童より59才にいたるまで約 2,000名について，vitalor を使用して肺換機能を測定し 势。

前報にひきつづき今回は妢力性肺活量 (FVC) の予測
武を算出し，計算の便利のため,ノモグラムを作製し た。

FVC と体格との関係では身長, 体重, 胸囲のらち身 長と最も密接な関係が認められた。

FVC は身長の二乘と添济比例し，同一身長では男性 は女性より高值を示し，年令注るる差をみられたので，

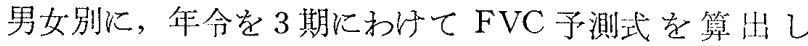
た。

男性では

$$
\begin{aligned}
8 \sim 19 才 \quad \mathrm{FVC}= & (71.01+4.811 \text { Age, years }) \\
& (\text { Height, } \mathrm{cm})^{2} \times 10^{-3} \\
20 \sim 44 才 \quad \mathrm{FVC}= & (167.60-0.429 \text { Age, years }) \\
& (\text { Height, cm })^{2} \times 10^{-3} \\
45 \sim 59 才 \quad \mathrm{FVC}= & (185.71-0.954 \text { Age, years })
\end{aligned}
$$$$
\text { (Height, } \mathrm{cm})^{2} \times 10^{-3}
$$

女性では

$$
\text { 8〜16才 } \mathrm{FVC}=(82.61+2.755 \text { Age, yeas })
$$

(Height, $\mathrm{cm})^{2} \times 10^{\cdot 3}$

$17 \sim 34$ $\mathrm{FVC}=(129.94-0.077$ Age, years $)$

(Height, $\mathrm{cm})^{2} \times 10^{-3}$

$35 \sim 59 \Varangle \quad \mathrm{FVC}=(135.85-0.521$ Age, years $)$

(Height, $\mathrm{cm})^{2} \times 10^{-3}$

といら予測式をえた。

以上の予測式の値を算出するためのノモグラムを作製 した。

な拈一秒率の基準倠については，体格との関保は汪之 んど認められず，一般に女性は男性より高侮を示し，年 少者は成人より高値を示している。

\section{労 働 生 理}

\section{0. 日常生活時におけるカテコールアミンとVMAの 尿中排泄量について}

小自綾子, 守 和子(学衛研)

カテュールアミン (CA) の尿中排泄量は, 精神・身 体的活動の程度にしたがって变化し，正常の日常生活に おいては昼間多く夜間少ないことが知られている。そこ で，演者らは，CA の主要代謝産物であるバニルマンデ

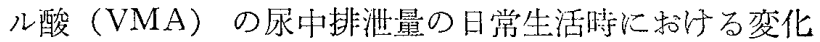
を検楌するため，普通の生活をいとなむ成人男子につい て尿中CA 拈よび VMA を測定した。

その結果, $\mathrm{CA}$ 排湘量は明らか炕昼間多く夜間少なか 